\title{
Regional socioeconomic indicators and ethnicity as predictors of regional infant mortality rate in Slovakia
}

\author{
Katarina Rosicova $\cdot$ Andrea Madarasova Geckova • \\ Jitse P. van Dijk · Jana Kollarova · Martin Rosic • \\ Johan W. Groothoff
}

Received: 29 October 2009/ Revised: 29 April 2010 / Accepted: 12 September 2010/ Published online: 26 October 2010 (C) The Author(s) 2010. This article is published with open access at Springerlink.com

\begin{abstract}
Objective Exploring the associations of regional differences in infant mortality with selected socioeconomic indicators and ethnicity could offer important clues for designing public health policy measures.

Methods Data included perinatal and infant mortality in the 79 districts of the Slovak population in 2004. Linear regression was used to analyse the contribution of education, unemployment, income and proportion of Roma
\end{abstract}

This paper belongs to the special issue "Migrants and ethnic minorities in Europe: new challenges for public health research and practice".

\section{K. Rosicova $(\square)$}

Kosice Self-Governing Region, Department of Regional Development and Land-Use Planning, Kosice, Slovakia e-mail: katarina.rosicova@vucke.sk

K. Rosicova · A. Madarasova Geckova · J. P. van Dijk Kosice Institute for Society and Health - Graduate School, P.J. Safarik University, Kosice, Slovakia

K. Rosicova $\cdot$ A. Madarasova Geckova Health Psychology Unit, Public Health Institute,

Medical Faculty, P.J. Safarik University, Kosice, Slovakia

J. Kollarova

Regional Public Health Authority of Kosice,

Department of Health Promotion, Kosice, Slovakia

\section{Rosic}

Faculty of Humanities and Natural Sciences,

University of Presov, Presov, Slovakia

J. P. van Dijk - J. W. Groothoff

Department of Social Medicine,

University Medical Centre Groningen,

University of Groningen, Groningen, The Netherlands population on regional differences in perinatal and infant mortality rates.

Results All the explored socioeconomic indicators and ethnicity individually contributed significantly to both perinatal and infant mortality, with the exception of income. In the model exploring the influence of all these variables together on perinatal and infant mortality, only the effect of the proportion of Roma population remained significant. This model explained $34.9 \%$ of the variance for perinatal and $36.4 \%$ of the variance for infant mortality.

Conclusions Living in Roma settlements indicates an accumulation of socioeconomic disadvantage. Health literacy, health-related behaviour and many other factors might contribute to the explanation of the differences in infant mortality, and a better understanding of these processes might help us to design tailored interventions.

Keywords Infant mortality - Regional differences . Roma population $\cdot$ Socioeconomic indicators

\section{Introduction}

Infant mortality rate is one of the most important indicators of the general level of health or well being of a given community and of its environmental and socioeconomic development (Fantini et al. 2006; Murray et al. 2000; Reidpath and Allotey 2003; Zatonski et al. 2006).

Several analytical frameworks are used for studying the determinants of child survival (Ansari et al. 2003; Mosley and Chen 1984; Titaley et al. 2008) based on the premise that all social and economic determinants of child mortality operate through a common set of biological mechanisms, or proximate determinants, to exert an impact on mortality. Perinatal and infant mortality are associated with a number of 
sociodemographic indicators such as ethnic groups (Pamuk et al. 1998), family income (Dominguez-Berjon et al. 1999; Finch 2003; Kawachi et al. 1997; Macinko et al. 2004; Mayer and Sarin 2005), unemployment (Titaley et al. 2008), mother's or father's social class (Gissler et al. 2003) and education of the mother (Bobak et al. 2005; Dostal et al. 2010; Singh and Kogan 2007). Moreover, it is known that infant mortality tends to be higher in countries with greater social and health-related inequalities and tends to rise in countries that have suffered from substantial socioeconomic, cultural and political disruption (Zatonski et al. 2006).

In many countries, individual-based data on mortality are not available, while area-based data are mostly available and comparable. Focusing on lower geographical levels (e.g. areas, regions, districts) seems to be more accurate than country-wise comparisons or state level analysis, but studies based on sub-national entities are less common (Borrell et al. 2008; Congdon and Southall 2004; Dominguez-Berjon et al. 1999; Kosa et al. 2007; Martuzzi et al. 1998; Rosicova et al. 2009; Vazquez-Vizoso et al. 1993).

While both socioeconomic and health care factors contribute to the existence of geographical inequalities in infant mortality, it has been suggested that the influence of each of these two factors is different depending on the level of the economic development of each area (DominguezBerjon et al. 1999). Many existing studies (Borrell et al. 2008; Dominguez-Berjon et al. 1999; Gissler et al. 2003; Hales et al. 1999; Kawachi et al. 1997; Macinko et al. 2004; Sousa et al. 2010) are only partial in the sense of considering the impact of one factor or dimension of inequality (e.g. income, occupation or social position, social class) on mortality, and not considering the interrelated impact of several dimensions of variation.

Although international differences in perinatal and infant mortality have been established, partly related to measures of national prosperity, less is known about sub-national geographical variations at the small-area level. The aim of the present work is to study the geographic distribution of perinatal and infant mortality by small area and to assess the association between social deprivation and perinatal and infant mortality in the districts of Slovak Republic.

\section{Methods}

\section{Study population}

The study population covers all inhabitants of the Slovak Republic in the year 2004. In order to explore regional differences, the study population was analysed at the district level. The Slovak Republic is divided into 79 districts, five of which constitute the capital city Bratislava, and four districts constitute the second largest city, Košice.
Data

The basic data consist of absolute population numbers and numbers of live births, stillbirths and deaths in the districts of the Slovak Republic in the year 2004 (Table 1). These data reflect the monitoring of natural changes in the population of the Slovak Republic in 2004, and were obtained from the Statistical Office of the Slovak Republic. Registration of the population is recorded as accurately as possible; health facilities are obliged to send a report on birth on the first working day after a child is born, and a report on death within three working days after inspection of the dead person.

Educational level, registered unemployment rate, income and the Roma population were used as socioeconomic indicators influencing the mortality rate. All indicators were calculated for each district, because data are available and rather reliable at the district level. For educational levels, the percentage of inhabitants over 16 years of age with only elementary education and that of those with uncompleted elementary education were used; both were based on the 2001 population census from the Statistical Office of the Slovak Republic. The mean proportion of inhabitants with only elementary or uncompleted elementary education in the Slovak Republic was $26.71 \%$ (ranging from 11.33 to $38.31 \%$ per district). Data on the number of registered unemployed was obtained from the tally of the Office of Labour, Social Affairs and Family of the Slovak Republic. The registered unemployment rate was expressed as the proportion of the number of unemployed inhabitants to the number of economical active inhabitants, with the mean value per district at $13.1 \%$ in the year 2004 (ranging from 2.3 to $28.7 \%$ ). Income level [average monthly gross payment in Slovak Crowns (SKK)] was based on data from the Statistical Office of the Slovak Republic. At the district level, income data are available only for companies with 20 or more employees (about $60 \%$ of all companies in Slovakia). The mean monthly income level in districts of the Slovak Republic was 16,923 SKK ( $€ 561$ ) in the year 2004, ranging from 11,050 to 27,289 SKK ( $€$ 366- $€ 905)$. The percentage of the Roma population living in settlements was obtained from the sociographic mapping conducted by the Office of the Government Plenipotentiary for Roma Community from the year 2004. The average percentage of Roma per district was $5.26 \%$ (ranging from 0.0 to $26.63 \%$ ).

Measures of mortality

Mortality rates were calculated for each district of the Slovak Republic. Perinatal mortality rate is expressed as the number of stillbirths and deaths under 7 days of age per number of live births. Infant mortality rate is expressed as 


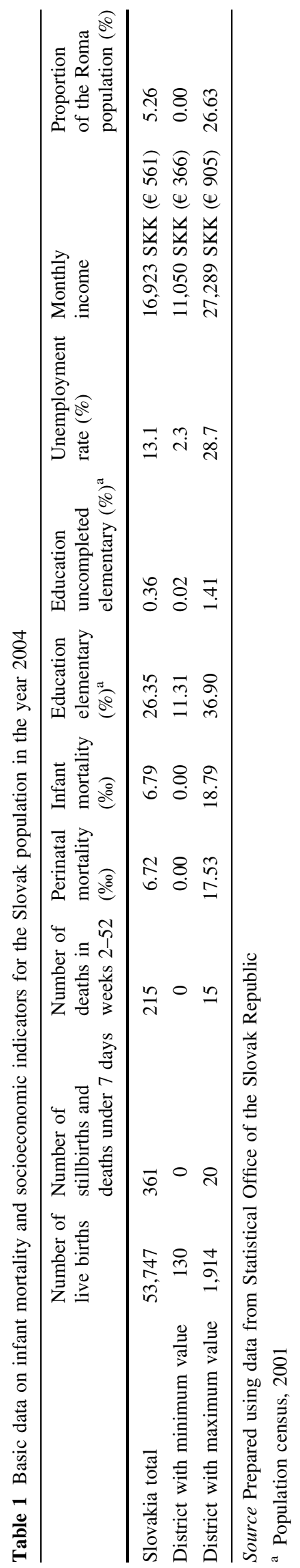

the number of deaths under 1 year of age per number of live births. To highlight the differences between perinatal and infant mortality, we also calculated mortality in weeks 2-52 (mortality after the seventh day to the end of the first year of life), which was expressed as the number of deaths over 7 days and under 1 year of age per number of live births. This mortality was determined only for statistical comparisons of influence of selected indicators to mortality, and has no official, demographical and statistical support.

Statistical analysis

The effects of education, unemployment, income and the Roma minority proportion on regional differences in perinatal and infant mortality were explored using linear regression analysis. First, the crude effect of each factor was explored separately and then all factors were included into the final model. Analyses were done using SPSS version 14.0.

\section{Results}

Study population

The number of inhabitants in the Slovak Republic as of July 12004 was 5,382,574 (48.5\% men). The mean number of inhabitants per district was 68,134 persons, ranging from 12,421 to 163,647 inhabitants.

Perinatal and infant mortality

The total number of live births was 53,747, and the number of stillbirths and deaths under 7 days of age was 361 $(6.72 \%)$, which is the figure for perinatal mortality. The total number of deaths under 1 year of age, not including stillbirths, was 365 (6.79\%o).

The perinatal and infant mortality rates in the districts of the Slovak Republic in the year 2004 are shown in Figs. 1 and 2. Districts of the Slovak Republic can be divided into two specific regions by perinatal mortality. The region of the western part of the Slovak Republic has a relatively low perinatal mortality rate, and the regions of Central and East Slovakia have a relatively high perinatal mortality rate. The majority of the districts (43 from 79 ) attained a lower perinatal mortality rate than the average national perinatal mortality rate, which was $6.72 \%$ in the year 2004 (Fig. 1).

Figure 2 shows the infant mortality rate. Districts in the south and central part of the West Slovakia are among those with the lowest infant mortality rate. In contrast, districts in the eastern part of Slovakia, especially in the 


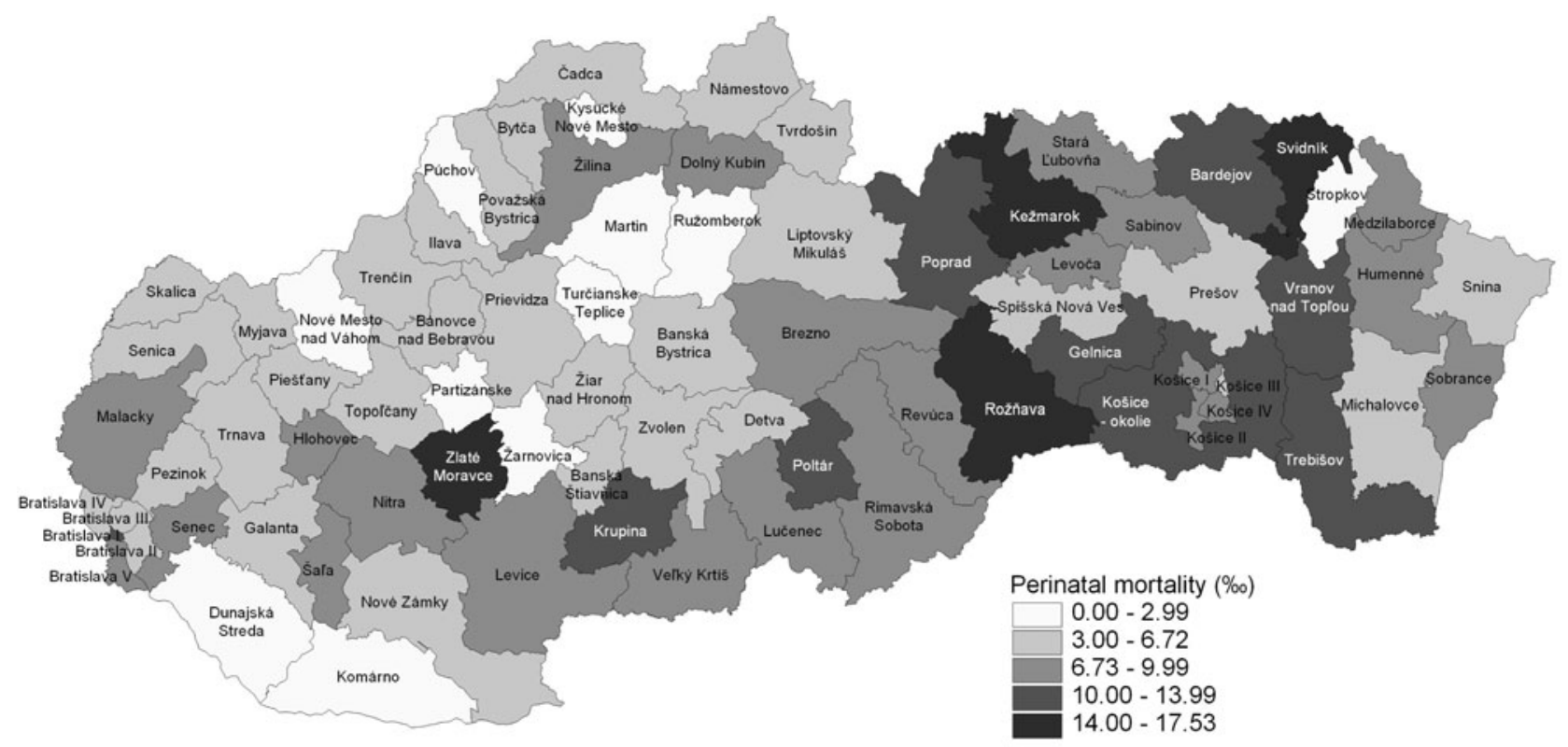

Perinatal mortality rate of the Slovak Republic $=6.72 \%$

Fig. 1 Perinatal mortality rate by districts in the Slovak Republic in the year 2004. Source: Prepared using data from Statistical Office of the Slovak Republic

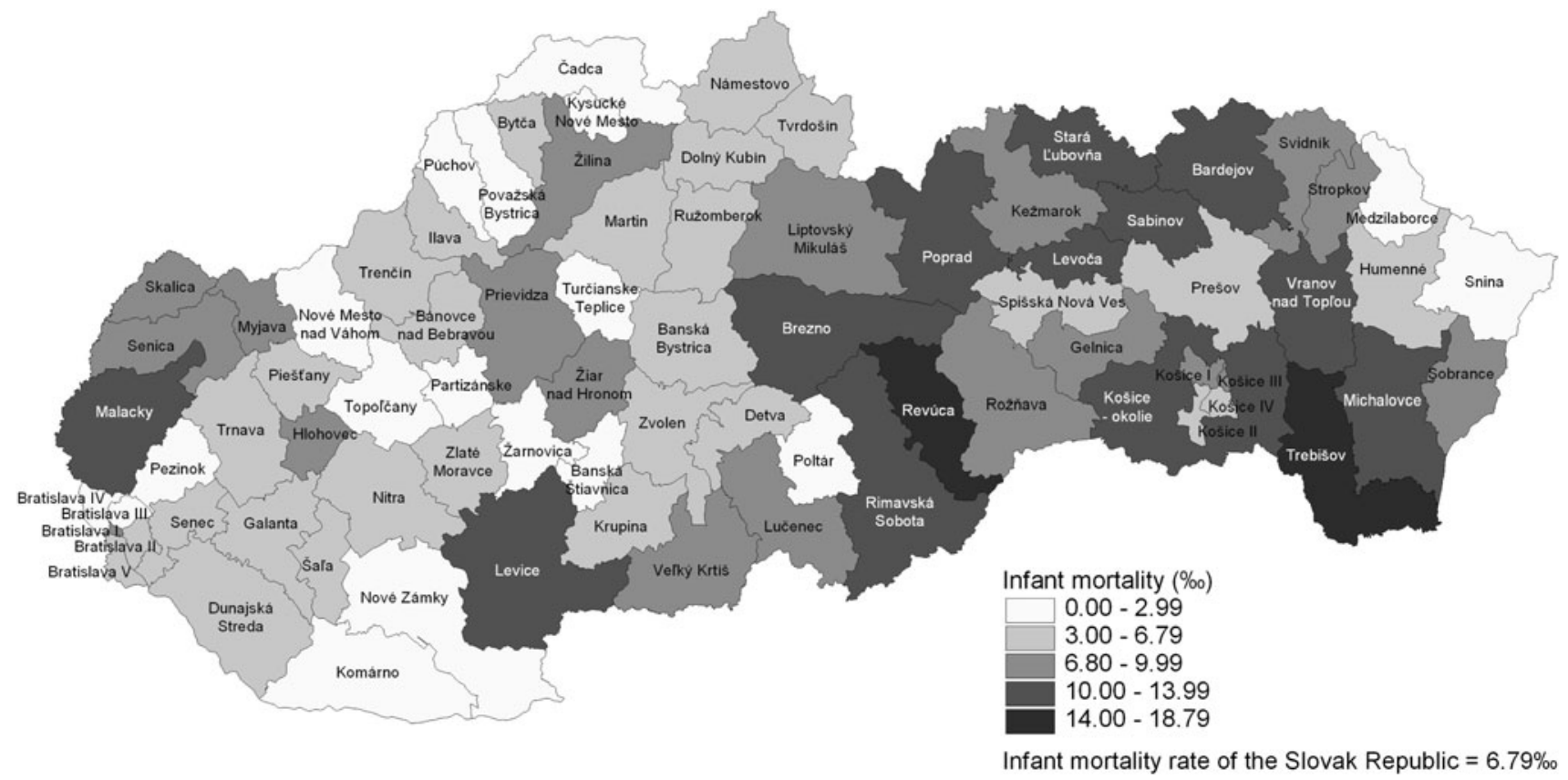

Fig. 2 Infant mortality rate by districts in the Slovak Republic in the year 2004. Source: Prepared using data from Statistical Office of the Slovak Republic

central part of East Slovakia, are among those with the highest infant mortality rate. Compared with the infant mortality rate at the national level, which reached a value of $6.79 \%$ in the year 2004 , the majority of the districts ( 45 from 79) achieved a lower mortality rate than the average rate for the Slovak Republic (Fig. 2).
Education, unemployment, income and Roma population

Table 2 presents the results of the linear regression between the rates of perinatal, infant mortality, and mortality in weeks 2-52 in the districts of the Slovak Republic, 
Table 2 Linear regression between perinatal and infant mortality rate and socioeconomic indicators in the year 2004—crude effect of each factor

\begin{tabular}{|c|c|c|c|c|c|c|c|c|c|c|c|c|}
\hline \multirow{3}{*}{$\begin{array}{l}\text { Socioeconomic indicators } \\
\text { (separately) }\end{array}$} & \multicolumn{4}{|c|}{ Perinatal mortality } & \multicolumn{4}{|c|}{ Infant mortality } & \multicolumn{4}{|c|}{ Mortality in weeks $2-52$} \\
\hline & \multicolumn{2}{|c|}{$\begin{array}{l}\text { Unstandardised } \\
\text { coefficients }\end{array}$} & \multirow[t]{2}{*}{ Significance } & \multirow[t]{2}{*}{$R^{2}$} & \multicolumn{2}{|c|}{$\begin{array}{l}\text { Unstandardised } \\
\text { coefficients }\end{array}$} & \multirow[t]{2}{*}{ Significance } & \multirow[t]{2}{*}{$R^{2}$} & \multicolumn{2}{|c|}{$\begin{array}{l}\text { Unstandardised } \\
\text { coefficients }\end{array}$} & \multirow[t]{2}{*}{ Significance } & \multirow[t]{2}{*}{$R^{2}$} \\
\hline & $\beta$ & $\begin{array}{l}\text { Standard } \\
\text { error }\end{array}$ & & & $\beta$ & $\begin{array}{l}\text { Standard } \\
\text { error }\end{array}$ & & & $\beta$ & $\begin{array}{l}\text { Standard } \\
\text { error }\end{array}$ & & \\
\hline \multicolumn{13}{|l|}{ Education } \\
\hline Elementary & 0.178 & 0.070 & $0.013 *$ & 0.078 & 0.165 & 0.076 & $0.032 *$ & 0.058 & 0.096 & 0.059 & 0.103 & 0.034 \\
\hline Uncompleted elementary & 3.458 & 1.476 & $0.022 *$ & 0.067 & 4.791 & 1.540 & $0.003 * *$ & 0.112 & 4.122 & 1.159 & $0.001 * *$ & 0.141 \\
\hline Unemployment rate & 0.243 & 0.060 & $0.000 * * *$ & 0.174 & 0.234 & 0.066 & $0.001 * *$ & 0.141 & 0.168 & 0.051 & $0.001 * *$ & 0.124 \\
\hline Income & 0.000 & 0.000 & 0.381 & 0.010 & 0.000 & 0.000 & 0.292 & 0.014 & 0.000 & 0.000 & 0.267 & 0.016 \\
\hline $\begin{array}{l}\text { Proportion of Roma } \\
\text { population }\end{array}$ & 0.364 & 0.059 & $0.000 * * *$ & 0.329 & 0.393 & 0.063 & $0.000 * * *$ & 0.336 & 0.257 & 0.051 & $0.000 * * *$ & 0.245 \\
\hline
\end{tabular}

Source Prepared using data from Statistical Office of the Slovak Republic

$R^{2}$ explained variance

$* p \leq 0.05$

$* * p \leq 0.01$

$* * * p \leq 0.001$ (2-tailed)

and the separate socioeconomic indicators. In this model, the variables were entered consecutively to explore the effects separately. Dependent variables are the rates of perinatal, infant mortality and mortality in weeks 2-52 separately. All the variables except income showed a significant effect on perinatal mortality. The situation is similar with regard to infant mortality: all the variables except income had a significant effect on infant mortality. In terms of mortality, in weeks 2-52 all the variables except income and elementary education had a significant effect.
Table 3 shows the linear regression presenting the relationship between socioeconomic indicators in the districts of the Slovak Republic and the rates of perinatal, infant mortality and mortality in weeks $2-52$. The model explores the influence of all variables together on all the three mortality rates. The model explains $34.9 \%$ of the variance in perinatal mortality rate, $36.4 \%$ of the variance in infant mortality rate and $30.3 \%$ of the variance in mortality in weeks 2-52. Only the proportion of the Roma population contributed to the prediction of perinatal, infant mortality and mortality in weeks $2-52$ in the districts of the

Table 3 Linear regression between perinatal and infant mortality rate and socioeconomic indicators in the year 2004-all variables

\begin{tabular}{|c|c|c|c|c|c|c|c|c|c|}
\hline \multirow[t]{3}{*}{ Socioeconomic indicators } & \multicolumn{3}{|c|}{ Perinatal mortality } & \multicolumn{3}{|c|}{ Infant mortality } & \multicolumn{3}{|c|}{ Mortality in weeks $2-52$} \\
\hline & \multicolumn{2}{|c|}{$\begin{array}{l}\text { Unstandardised } \\
\text { coefficients }\end{array}$} & \multirow[t]{2}{*}{ Significance } & \multicolumn{2}{|c|}{$\begin{array}{l}\text { Unstandardised } \\
\text { coefficients }\end{array}$} & \multirow[t]{2}{*}{ Significance } & \multicolumn{2}{|c|}{$\begin{array}{l}\text { Unstandardised } \\
\text { coefficients }\end{array}$} & \multirow[t]{2}{*}{ Significance } \\
\hline & $\beta$ & $\begin{array}{l}\text { Standard } \\
\text { error }\end{array}$ & & $\beta$ & $\begin{array}{l}\text { Standard } \\
\text { error }\end{array}$ & & $\beta$ & $\begin{array}{l}\text { Standard } \\
\text { error }\end{array}$ & \\
\hline \multicolumn{10}{|l|}{ Education } \\
\hline Elementary & -0.005 & 0.109 & 0.965 & -0.117 & 0.115 & 0.315 & -0.166 & 0.092 & 0.077 \\
\hline Uncompleted elementary & -1.021 & 1.695 & 0.549 & 1.499 & 1.792 & 0.406 & 2.663 & 1.435 & 0.068 \\
\hline Unemployment rate & 0.055 & 0.110 & 0.618 & -0.079 & 0.116 & 0.502 & -0.025 & 0.093 & 0.789 \\
\hline Income & 0.000 & 0.000 & 0.316 & $E$ & 0.000 & 0.963 & $E$ & 0.000 & 0.621 \\
\hline Proportion of Roma population & 0.383 & 0.100 & $0.000 * * *$ & 0.489 & 0.106 & $0.000 * * *$ & 0.293 & 0.085 & $0.001 * *$ \\
\hline$R^{2}$ & 0.349 & & & 0.364 & & & 0.303 & & \\
\hline
\end{tabular}

Source: Prepared using data from Statistical Office of the Slovak Republic

$R^{2}$ explained variance

$* * p \leq 0.01$

$* * * p \leq 0.001$ (2-tailed) 
Slovak Republic. The effect of the other variables on perinatal, infant mortality and mortality in weeks $2-52$ was not significant.

Figure 3 shows the spatial distribution of the Roma population living in settlements by districts. The Slovak republic is divided into two parts-districts in the western part of the Slovakia are characterised by small proportions of the Roma population living in settlements, in contrast with districts in the eastern part of Slovakia, especially in the south and central part of East Slovakia, which are among those with high proportions of the Roma population living in settlements (Fig. 3).

\section{Discussion}

The results of our study point out the relationship between selected socioeconomic indicators (educational level, unemployment rate, income), ethnicity (population living in Roma settlements), and perinatal and infant mortality rate and mortality rate in weeks $2-52$ in the districts of the Slovak Republic. Looking at the factors separately, a significant effect of educational level, unemployment rate and the proportion of people living in Roma settlements on perinatal and infant mortality was observed, while income had no significant effect on perinatal and infant mortality and mortality rate in weeks 2-52. The model including all socioeconomic factors and ethnicity together showed that only the proportion of people living in Roma settlements have a significant effect on perinatal and infant mortality, and mortality rate in weeks $2-52$.

The number of Roma living in Europe ranges between 5 and 10 million; they are a minority group within the European Union, with most of the Roma population living in the new member states-in particular, Romania, Bulgaria, Hungary and Slovakia (Kosa et al. 2007). According to various estimates, about 430,000 Roma live in Slovakia (8\% of the Slovak population), and about twothirds of them are of productive age. The Roma represent a large minority in the Slovak population (Marcincin and Marcincinova 2009). Roma are characterised by an extremely high degree of territorial segregation, poverty and perceived discrimination (EU-MIDIS 2009; Vasecka and Dzambazovic 2000). Furthermore, the Roma population is characterised by a low educational level and high unemployment rate (EU-MIDIS 2009; Vasecka and Dzambazovic 2000).

Worse birth outcomes (shorter gestation length, lower birth weight) among Roma in comparison with non-Roma mothers were confirmed in Czech Republic (Bobak et al. 2005; Rambouskova et al. 2009), Slovakia (Rimarova et al. 2004), Hungary (Joubert 1991) and Spain (Sola et al. 2008). Higher morbidity (incidence of bronchitis, pneumonia, viral diseases, otitis media, influenza and intestinal infections) of Roma children 0-2 years of age as compared

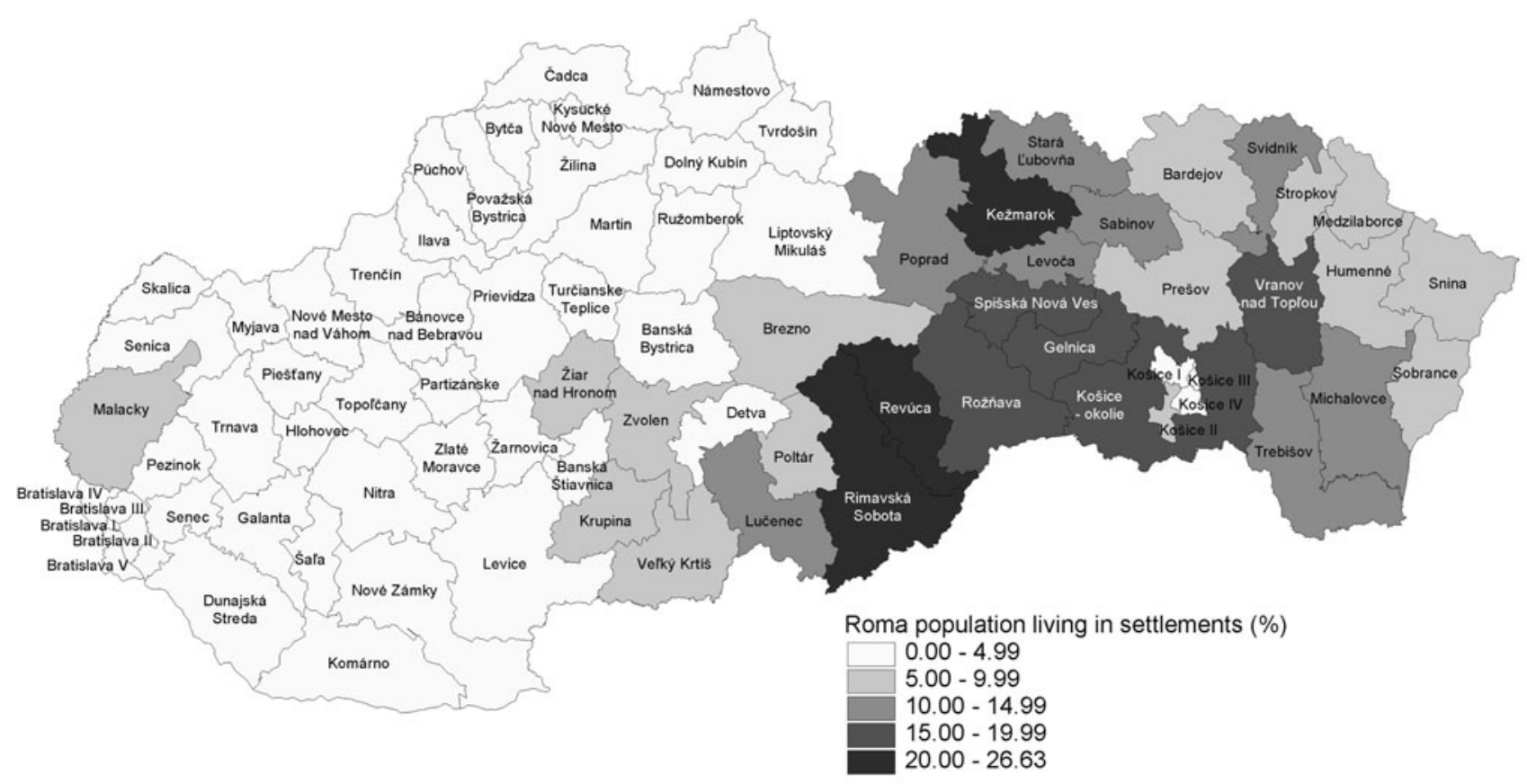

Proportion of the Roma population in the Slovak Republic $=5.26 \%$

Fig. 3 The proportion of the Roma population living in settlements by districts in the Slovak Republic in the year 2004. Source: Prepared using data from Statistical Office of the Slovak Republic 
to non-Roma children was confirmed by Dostal et al. (2010).

Worse birth outcomes as well as higher morbidity in early childhood used to be attributed to maternal education (Bobak et al. 2005; Dostal et al. 2010), maternal smoking (Dostal et al. 2010; Rambouskova et al. 2009; Rimarova et al. 2004), a lack of prenatal care (Sola et al. 2008) and poor living conditions (Monasta et al. 2008). Incidence of health problems among Roma children aged 0-5 years living in Roma settlements was associated with years spent living at the camp, overcrowding, housing conditions, use of wood-burning stoves, the presence of rats and issues related to the quality of sanitation and drains (Monasta et al. 2008). It may be concluded that there are several indices showing that the proportion of Roma living in settlements might contribute to regional differences in infant mortality.

It is possible to identify several hypotheses that may explain the worse health of the Roma in the literature compared to the majority population (Bastos et al. 2010; Dressler et al. 2005; Peters et al. 2009; Wilkinson and Marmot 1998). (1) Observed differences in health may be due to differences in living conditions, different access to goods and services, and the extent of poverty, meaning the major cause of these differences is not ethnicity but different socioeconomic characteristics. There are studies confirming the contribution of socioeconomic characteristics in the explanation of health differences between Roma and non-Roma (Kolarcik et al. 2009; Vokó et al. 2009). (2) Cultural differences are the cause of differences in health literacy, in health-related behaviour (nutritional habits, use of psychoactive substances, physical activity, disease prevention), which lead to gaps in health (Ostrihonova and Beresova 2010; Vivian and Dundes 2004). (3) The psychosocial hypothesis points to the health consequences of stress from discrimination, social exclusion, material and financial deprivation and lower socioeconomic position (Williams and Mohammed 2009). (4) The conditions in early childhood may be a disadvantage, and this disadvantage tends to cumulate in each subsequent critical life period, which may result in widening differences in health over life, resulting in a shorter life expectancy (Wilkinson and Marmot 1998). Of particular interest is access to health care, which might be an important factor of infant mortality. Available indicators of health care (number of gynaecologist and number of beds in institutional care per region) did not contribute to the explanation of regional disparities in infant mortality (analyses not shown), perhaps because these indicators measure only physical availability of health care facilities. Despite the fact that there is a free access to health care guaranteed by law, and access to health care in a particular region, there might be several significant barriers from the side of the Roma population to benefit from health care like residential segregation (distance from health care facilities and obstacles to arranging a visit), low health literacy, prejudices and discrimination (Popper et al. 2009).

Strengths and limitations of the study

The limitations of the present study arise from the deficient databases of income and of the proportion of Roma population. We decided to focus on the population living in Roma settlements, but this definition did not include the whole variety of the Roma population; it did not include the Roma population living integrated with the majority population. The indicator of income (average monthly gross wage) is available only for companies with 20 and more employees at the district level in Slovakia. This phenomenon probably explains the lack of significance in our results regarding the relationship between income and perinatal and infant mortality in the districts of the Slovak Republic.

\section{Implications}

The majority of mortality studies focus on infant mortality up to 1 year of life as a whole (Congdon and Southall 2004; Finch 2003; Hales et al. 1999; Kawachi et al. 1997; Leigh and Jencks 2007; Macinko et al. 2004). As in our research, emphasis is put on studying particular components of infant mortality in order to find associations with the specific factors influencing them (Borrell et al. 2008; Dominguez-Berjon et al. 1999; Gissler et al. 2003; Martuzzi et al. 1998; Mayer and Sarin 2005; Singh and Kogan 2007; Vazquez-Vizoso et al. 1993). Different factors might be important for different components of infant mortality, e.g. educational and health literacy of the mother for infant mortality (Borrell et al. 2008; Singh and Kogan 2007), age of the mother (National Statistics 2005) or state health care spending as a proxy for access to health care for perinatal and neonatal (Mayer and Sarin 2005). Based on our findings, it seems that the patterns of the respective associations between selected socioeconomic factors and perinatal and infant mortality are very similar.

Our findings indicate the need for more and deeper research into mortality up to 1 year of age, its geographical distribution and socioeconomic factors, which increase its level. Further research might try to reveal the mechanisms which play a role in causing socioeconomic differences in infant mortality. Different access to health care between the Roma and non-Roma population, different quality of health care provided, health literacy, health-related behaviour and many other factors might contribute to the explanation of the differences in infant mortality, while on the other hand, a better understanding of these processes 
might help us to obtain tailored interventions. Special attention should be paid to the differences in accessibility of the offered services.

There are several measures which have the potential to decrease such differences: (1) Supporting the work of community health workers and stimulating the collaboration between community health workers, paediatricians and gynaecologists with the aim of overcoming the institutional barriers in the field of mother and child care for women living in Roma settlements (Kosa et al. 2007; Peters et al. 2009; Rechel et al. 2009); (2) Establishing an intensive and long-term health promotion programme for adolescent Roma women focused on reproductive health, prenatal care, parenting and family planning (Bobak et al. 2005); (3) Using financial stimuli (e.g. making the reception of certain social benefits depending on participation in prenatal care) to stimulate participation in prenatal care (Rambouskova et al. 2009); (4) enhancing access to the health care and social services systems with the aim of ensuring adequate immunisation, early treatment for ill children and social support for vulnerable children (Dostal et al. 2010).

Acknowledgments This work was supported by the Research and Development Support Agency under Contract No. APVV-20-028802, 20-038205, VEGA 1/0210/08 and partially supported by the Agency of the Slovak Ministry of Education for the Structural Funds of the EU, under project ITMS: 2622012005 (20\%).

Conflict of interest The authors declare that they have no competing interests.

Open Access This article is distributed under the terms of the Creative Commons Attribution Noncommercial License which permits any noncommercial use, distribution, and reproduction in any medium, provided the original author(s) and source are credited.

\section{References}

Ansari Z, Carson NJ, Ackland MJ, Vaughan L, Serraglio A (2003) A public health model of the social determinants of health. Soz Preventiv Med 48:242-251

Bastos JL, Celeste RK, Faerstein E, Barros AJD (2010) Racial discrimination and health: a systematic review of scales with focus on their psychometric properties. Soc Sci Med 70:1091-1099

Bobak M, Dejmek J, Solansky I, Sram RJ (2005) Unfavourable birth outcomes of the Roma women in the Czech Republic and the potential explanations: a population-based study. BMC Public Health 5:106

Borrell C, Cicera E, Ricart M, Pasarín MI, Salvador J (2008) Social inequalities in perinatal mortality in a Southern European city. Eur J Epidemiol 18:5-13

Congdon P, Southall H (2004) Small area variations in infant mortality in England and Wales in the inter-war period and their link with socio-economic factors. Health Place 10:363-382

Dominguez-Berjon MF, Benach J, Garcia-Arcal MD, Borrell C (1999) Infant and perinatal mortality in Spain 1981-1991: interprovincial variations in Autonomous Communities with extreme economic levels. Eur J Epidemiol 15:723-729
Dostal M, Topinka J, Sram RJ (2010) Comparison of the health of Roma and non-Roma children living in the district of Teplice. Int J Public Health 55:435-441

Dressler WW, Oths KS, Gravlee CC (2005) Race and ethnicity in public health research: models to explain health disparities. Annu Rev Anthropol 34:231-252

EU-MIDIS, European Union Minorities and Discrimination Survey. Main Results Report, 2009. European Union Agency for Fundamental Rights

Fantini MP, Stivanello E, Dallolio L, Loghi M (2006) Persistent geographical disparities in infant mortality rates in Italy (1999-2001): comparison with France, England, Germany, and Portugal. Eur J Public Health 16:429-432

Finch BK (2003) Early origins of the gradient: the relationship between socioeconomic status and infant mortality in the United States. Demography 40:675-699

Gissler M, Merilainen J, Vuori E, Hemminki E (2003) Register based monitoring shows decreasing socioeconomic differences in Finnish perinatal health. J Epidemiol Community Health 57:433-439

Hales S, Howden-Chapman P, Salmond C, Woodward A, Mackenbach J (1999) National infant mortality rates in relation to gross national product and distribution of income. Lancet 354:2047

Joubert K (1991) Size at birth and some sociodemographic factors in gypsies in Hungary. J Biosoc Sci 23:39-47

Kawachi I, Kennedy BP, Lochner K, Prothrow-Stith D (1997) Social capital, income inequality, and mortality. Am J Public Health 87:1491-1498

Kolarcik P, Madarasova Geckova A, Orosova O, van Dijk JP, Reijneveld SA (2009) To what extent does socioeconomic status explain differences in health between Roma and non-Roma adolescents in Slovakia? Soc Sci Med 68:1279-1284

Kosa Z, Szeles G, Kardos L, Kosa K, Nemeth R, Orszagh S, Fesus G, McKee M, Adany R, Voko Z (2007) A comparative health survey of the inhabitants of Roma settlements in Hungary. Am J Public Health 97:853-859

Leigh A, Jencks C (2007) Inequality and mortality: long-run evidence from a panel of countries. J Health Econ 26:1-24

Macinko JA, Shi L, Starfield B (2004) Wage inequality, the health system, and infant mortality in wealthy industrialized countries, 1970-1996. Soc Sci Med 58:279-292

Marcincin A, Marcincinova L (2009) Losses from the exclusion of Roma (Straty z vylúčenia Rómov). Open Society Foundation, Bratislava

Martuzzi M, Grundy C, Elliott P (1998) Perinatal mortality in an English health region: geographical distribution and association with socio-economic factors. Paediatr Perinat Epidemiol 12: 263-276

Mayer SE, Sarin A (2005) Some mechanisms linking economic inequality and infant mortality. Soc Sci Med 60:439-455

Monasta L, Andersson N, Ledogar RJ, Cockcroft A (2008) Minority health and small numbers epidemiology: a case study of living conditions and the health of children in 5 Foreign Romá Camps in Italy. Am J Public Health 98:2035-2042

Mosley WH, Chen LC (1984) An analytical framework for the study of child survival in developing countries. Popul Dev Rev 10:25-45

Murray CJL, Salomon JA, Mathers C (2000) A critical examination of summary measures of population health. Bull World Health Organ 78:981-994

National Statistics (2005) Infant and perinatal mortality by social and biological factors, 2004. Health Stat Q 28:62-66

Ostrihonova T, Beresova J (2010) Výskyt metabolického syndrómu a jeho rizikových faktorov u vybranej skupiny rómskeho obyvatelstva (Occurrence of metabolic syndrome and its risk factors amongst selected group of Roma inhabitants). Bratisl Med J $55: 7-14$ 
Pamuk E, Makuk D, Heck K, Reuben C (1998) Socioeconomic status and health chartbook. National Center for Health Statistics, Hyattsville

Peters J, Parry GD, Van Cleemput P, Moore J, Cooper CL, Walters SJ (2009) Health and use of health services: a comparison between gypsies and travellers and other ethnic groups. Ethnic Health 14:359-377

Popper M, Szegy P, Sarkozy S (2009) Rómska populácia a zdravie: Analýza situácie na Slovensku (Roma population and health. An analyses of the situation in Slovakia). Partners for Democratic Change, Madrid

Rambouskova J, Dlouhy P, Krizova E, Prochazka B, Hrncirova D, Andel M (2009) Health behaviors, nutritional status, and anthropometric parameters of Roma and non-Roma mothers and their infants in the Czech Republic. J Nutr Educ Behav 41:58-64

Rechel B, Blackburn CM, Spencer NJ, Rechel B (2009) Access to health care for Roma children in Central and Eastern Europe: findings from a qualitative study in Bulgaria. Int J Equity Health $8: 24$

Reidpath DD, Allotey P (2003) Infant mortality rate as an indicator of population health. J Epidemiol Community Health 57:344-346

Rimarova K, Ostro A, Bernasovska K, Holeczyova G (2004) Reproductive indicators of Roma mothers: cross-sectional study. In: Aghova L (ed) Living conditions on health. Public Health Office of the Slovak Republic, Bratislava, pp 110-114

Rosicova K, Madarasova Geckova A, van Dijk JP, Rosic M, Zezula I, Groothoff JW (2009) Socioeconomic indicators and ethnicity as determinants of regional mortality rates in Slovakia. Int J Public Health 54:274-282

Singh GK, Kogan MD (2007) Persistent socioeconomic disparities in infant, neonatal, and postneonatal mortality rates in the United States, 1969-2001. Pediatrics 119:e928-e939

Sola CP, Palomero AZ, Garcia-Algar O, Reguant FC, Pust AB, Oliveres XC, Combelles OV (2008) Hospital admission in newborns according to ethnicity and parents' country of origin in an urban area of Barcelona (Spain). Gac Sanit 22:555-564

Sousa E, Agudelo-Suárez A, Benavides FG, Schenker M, García AM, Benach J, Delclos C, López-Jacob MJ, Ruiz-Frutos C, RondaPérez E (2010) Immigration, work and health in Spain: the influence of legal status and employment contract on reported health indicators. Int J Public Health 55:443-451

Titaley CL, Dibley MJ, Agho K, Roberts CL, Hall J (2008) Determinants of neonatal mortality in Indonesia. BMC Public Health 8:232

Vasecka M, Dzambazovic R (2000) Socialno-ekonomicka situacia Romov na Slovensku ako potencionalnych migrantov a ziadatelov o azyl v krajinach EU. Socialna a ekonomicka situacia potencionalnych ziadatelov o azyl zo Slovenskej Republiky. International Organization for Migration (IOM), Geneva, pp 17-62

Vazquez-Vizoso F, Castilla J, Pollan M, Lopez-Abente G (1993) Assessment of trends in geographical inequalities in infant mortality. Soc Sci Med 37:413-417

Vivian C, Dundes L (2004) The crossroads of culture and health among the Roma (Gypsies). J Nurs Scholarsh 36:89-91

Vokó Z, Csépe P, Németh R, Kósa K, Széles G, Ádány R (2009) Does socioeconomic status fully mediate the effect of ethnicity on the health of Roma people in Hungary? J Epidemiol Community Health 63:455-460

Wilkinson RG, Marmot M (1998) Social determinants of health. The solid facts. WHO, Copenhagen

Williams DR, Mohammed SA (2009) Discrimination and racial disparities in health: evidence and needed research. J Behav Med 32:20-47

Zatonski W, Mikucka M, La Vecchia C, Boyle P (2006) Infant mortality in Central Europe: effects of transition. Gac Sanit 20:63-66 